\title{
Special Issue: Basaltic Rocks of Various Tectonic Settings -Selected papers from the 29th International Geological Congress, Symposium II-8-6-
}

Preface

\author{
Hiroaki Sato, ${ }^{1}$ KUla C. MisRa ${ }^{2}$ and HiroKaZU FuJIMAKI ${ }^{3}$ \\ ${ }^{1}$ Department of Natural Environmental Sciences, Hiroshima University, Higashi-Hiroshima 724, Japan \\ ${ }^{2}$ Department of Geological Sciences, University of Tennessee, Knoxville, Tennessee, U.S.A. \\ ${ }^{3}$ Department of Science of Earth Material, Tohoku University, Sendai 980, Japan
}

This special issue of Geochemical Journal includes some of the papers presented at the symposium with the same title in the 29th International Geological Congress held at Kyoto in August, 1992. The symposium included 10 oral and 15 poster presentations. Of the 9 manuscripts submitted for this special issue, 5 were chosen for publication after careful review. Although restricted in scope and material as the geochemical and petrological investigation of basaltic rocks on the terrestrial planet, the present issue does provide some insight into the present state of understanding of basalt petrogenesis in some tectonic settings on the earth. Followings give brief view of the papers included in this issue.

The first three papers discuss the petrogenesis of the Tertiary basalts and related rocks relevant to the opening of the Japan Sea. Uto, Takahashi, Nakamura, and Kaneoka present new $\mathrm{K}-\mathrm{Ar}$ and geochemical data on basalts and related volcanic rocks of Oki-Dogo Island, which is situated north of the Southwest Japan arc. Syn-extensional volcanic rocks show geochemical signature of arc basalts, such as $\mathrm{Nb}$ - and Ta-depletion and $\mathrm{Ba}$ - and $\mathrm{K}_{2} \mathrm{O}$-enrichment relative to MORB, whereas, younger basalts $(5.5-0.6 \mathrm{Ma})$ do not. The authors suggest that the arc-like geochemistry of the synextensional lavas may have been caused by partial melting of subcontinental lithosphere, which had been metasomatized by fluids from previously subducted slabs.

A similar conclusion is reached by Miyake, who describes basalt and related volcanic rocks of Shimane Peninsula on the Japan Sea coast of Southwest Japan arc. He argues that the arc signature of the middle Miocene basalts resulted from the melting of subarc lithospheric mantle which had been metasomatized by subduction-related fluids. He also discusses the fractional crystallization model for the generation of the associated felsic rocks.

Ohki, Shuto, and Kagami demonstrate that the Tertiary to Quaternary basaltic rocks of the Northeast Japan arc may be divided into two groups on the basis of $\mathrm{Sr}$ and $\mathrm{Nd}$ isotopic data: a high-Sr $r_{i}$ group $\left({ }^{87} \mathrm{Sr} /{ }^{86} \mathrm{Sr}=0.7040-0.7058, \varepsilon_{\mathrm{Nd}}=\right.$ $0-3)$ and low- $\mathrm{Sr}_{\mathrm{i}}$ group $\left({ }^{87} \mathrm{Sr} /{ }^{86} \mathrm{Sr}=0.7029\right.$ $\left.0.7040, \varepsilon_{\mathrm{Nd}}=3-8\right)$. On the back-arc side of the northeastern Japan, high- $\mathrm{Sr}_{\mathrm{i}}$ basalts erupted before middle Miocene, whereas low-Sri basalts predominated during late Miocene through Quaternary. On the trench side of Northeast Japan arc, similar temporal variation of isotopic signature of basaltic rocks is observed, but with slightly higher $\mathrm{Sr}_{\mathrm{i}}$ and lower $\varepsilon_{\mathrm{Nd}}$ compositions. Ohki et al. ascribe the compositional differences to layering in the upper mantle source region consisting of upper isotopically undepleted and lower isotopically depleted peridotites. Strong mantle upwelling during the opening of the Japan sea may have caused partial melting of the lower depleted layer of the mantle.

The two other papers deal with basaltic rocks of intra-plate environments. Bardintzeff, Leyrit, 
Guillou, Guille, Bonin, Giret and Brousse describe two cases of transition between tholeiitic and alkalic basalts from Fangataufa and Kerguelen islands. The thin transition zone with interstratified tholeiitic and alkalic basalts, which is well exposed in Hawaii, was not observed in both islands. Geochemical data suggest a single source for the short-lived Fangataufa oceanic island, but more than one source for the long-lived Kerguelen magmatic system.

Al-Malabeh presents petrographic and geochemical data on two volcanic cones from the Intra-continental plateau basalts of Harra ElJabban, NE-Jordan, which constitute part of flood basalts with up to $10^{5} \mathrm{~km}^{3}$ in volume. The basalts are mostly classified as basanite. The primary nature of the magma is indicated by high $\mathrm{MgO}$ content (>8 wt.\%), high Mg-number (0.69-0.75), low silica content (around 45 wt.\%), and high $\mathrm{Cr}$ and $\mathrm{Ni}$ contents (147-353 and 180-341 ppm, respectively). The magma was probably generated by low degrees of partial melting (3-8\%) of garnet peridotite at $>100 \mathrm{~km}$ depth.

Publication of the present issue in Geochemical Journal was made possible through the support of the executive editor, Dr. Yukihiro Matsuhisa. The papers in this special issue have benefited from careful reviews by the following persons: Asish R. Basu, Mark Feigenson, Shunso Ishihara, Tetsumaru Itaya, Ichiro Kaneoka, P. Krishnamurthy, John J. Mahoney, Yukihiro Matsuhisa, Yasuyuki Miyake, Tsugio Shibata, Robert J. Stern, Shigeko Togashi, and Osamu Ujike. We are grateful to them for their help. 